\title{
Margin Trading and Securities Lending, Investor Sentiments and the Volatility of Chinese Securities Market
}

\author{
Huiting Huang \\ College of Economics, Jinan University, Guangzhou, China \\ Email: huanght01@126.com
}

How to cite this paper: Huang, H.T. (2019) Margin Trading and Securities Lending, Investor Sentiments and the Volatility of Chinese Securities Market. American Journal of Industrial and Business Management, 9, 536-550.

https://doi.org/10.4236/ajibm.2019.93036

Received: February 22, 2019

Accepted: March 17, 2019

Published: March 20, 2019

Copyright $\odot 2019$ by author(s) and Scientific Research Publishing Inc. This work is licensed under the Creative Commons Attribution International License (CC BY 4.0). http://creativecommons.org/licenses/by/4.0/

\begin{abstract}
Whether margin trading and securities lending transaction help to stabilize the stock market or amplify stock market volatility is a topic that has long been a concern. Based on the perspective of volatility asymmetry, we use event analysis and ARMA-EGARCH-M model to empirically test whether China's margin trading and securities lending transactions can boost the bull market and aggravate the price decline in bear market. The empirical results show that the volatility of China's stock market was asymmetric. Margin trading transactions reduced the stock market volatility while securities lending transactions increased the stock market volatility. Since the trading volume of margin trading was much larger than the trading volume of securities lending, the stock market volatility decreased since the launch of margin trading and securities lending mechanism.
\end{abstract}

\section{Keywords}

Margin Trading, Securities Lending, Financial Stability, Stock Market Cycle, Asymmetric Volatility, ARMA-EGARCH-M Model

\section{Introduction}

Whether margin trading and securities lending transaction help to stabilize the stock market or amplify stock market volatility is a topic that has long been a concern. Scholars at home and abroad have conducted a lot of theoretical and practical research on this, but no consensus conclusion was reached so far.

He who supports the introduction of margin trading and securities lending mechanism believes that the lack of a two-way trading mechanism will lead to a unilateral stock market. When investors want to make a profit, they can only buy 
stocks and pull up the stock price. Once the stock price trends to decline, investors can only sell their stocks in order to avoid further losses, thus causing the stock price to fall further, forming a vicious circle. If a margin trading and securities lending mechanism is introduced, investors can make a profit not only by buying long but also by short selling, which helps to achieve a balance between the long and short power of the stock market.

He who argues against the introduction of margin trading and securities lending mechanism thinks that China's stock market is not mature enough. Investors used to buy on the upswing, and sell on the downswing. The herd effect is obvious. Most investors are keen on short-term speculation and chasing capital gains. Under this circumstance, margin trading and securities lending mechanism cannot play the role of stock market stabilizer, but in contrast, will intensify the stock market fluctuation.

\section{Literature Review}

The history of China's stock market development is relatively short, while investors' speculative sentiment is relatively strong, and the construction of market infrastructure is yet to be improved. In this context, there is a substantial divergence of opinions in the academic world about the impact of margin trading and securities lending transaction system on market volatility.

Theoretically, margin trading and securities lending transactions may increase stock market volatility. Investor sentiment may be the reason why stock market volatility increases. Investors' trading behavior is often influenced by emotions [1]. In the bull market, investors are more and more confident, and the probability of basic attribution errors and self-interest bias increases. When there is good news in the market, the tendency attribution tends to strengthen investor confidence, which in turn increases financing purchases (while reducing short selling). When there is bad news in the market, as facts are different from their psychological expectations, investors are psychologically nervous, and may take measures such as intentionally neglecting bad news and degrading their importance, thus reducing the reduction in financing purchases and short selling. In the bear market, investors are lack of confidence. When there is bad news in the market, investors' pessimism is strengthened, so they in turn reduce financing purchases and increase securities lending and short selling; when there is good news in the market, investors still think that the market will not continue to rise, so the increase in financing purchases volume and the reduction in short selling volume is relatively low.

However, investor rationality and arbitrage trading may reduce stock market volatility. One of the most important reasons for excessive stock market volatility is investors' overreaction, which creates favorable conditions for arbitrage trading. As investors often overreact to bad news in the bear market and overreact to the good news in the bull market, rational investors can use the margin financing mechanism to carry out arbitrage trading: increase the financing buy- 
ing after the bad news in the bear market, and increase short selling after good news in the bull market. Then they can wait until the stock market has a short-term reversal and close the position.

In practice, what is the impact of the introduction of margin trading and securities lending mechanism on the volatility of China's stock market? Most empirical studies show that margin trading has reduced the volatility of China's stock market. Short-selling constraints may lead to overvaluation of stock prices, and margin trading helps to curb stock price bubbles and improve stock pricing efficiency [2]. Since the launch of the mechanism the standard deviations, measures of skewness and outlier ratios of the stocks of margin trading were significantly lower than before [3]. Margin trading improves the information efficiency of stock prices and reduces the idiosyncratic fluctuation of stock prices [4]. Margin trading transactions reduced the stock market volatility, while short selling transactions increased the stock market volatility. Since the margin trading transactions are in larger scale than short selling transactions, the combined effect of the two was to reduce the stock market volatility [5].

However, some scholars hold different opinions. Xu Hongwei and Chen Xin believe that margin trading and securities lending transaction can only significantly reduce the probability of stock price plunging, and the impact on the probability of stock price inflation is not significant [6]. Li Fengsen pointed out that China's margin financing and securities lending mechanism has neither boosted the bull market nor exacerbated the bear market decline. Its impact on the cyclical fluctuation of the stock market is neutral [7]. Lin Xiangyou believe that from the perspective of extraordinary returns, margin trading and securities lending transactions have the effect of helping to accelerate the rise and decline of stock prices, and the decline effect is stronger than the boosting effect [8]. Zhu Jian and Fang Junxiong pointed out that China's margin trading and securities lending system not only failed to effectively reduce the risk of stock price collapse of the underlying stocks, but in fact exacerbated the risk. The deeper reason is that there are inherent defects in the design of China's margin financing and securities lending system. However, the existing research mainly focus on the effect of margin financing and securities lending system on the short term stock market volatility based on daily or monthly data, without taking volatility asymmetry into consideration [9].

The asymmetry of stock market volatility was first proposed by Black (1976). He found that stock price changes and volatility changes were significantly negatively correlated: volatility tends to decrease when stock prices rise, and volatility tends to increase when stock prices fall. The reason is that stock price changes and volatility changes are reciprocal causation.

Since Black proposed the asymmetry of stock market volatility [10], many scholars used different methods to repeatedly study the stock market data in different markets and different periods. And they found that stock market volatility asymmetry exists in stock markets in various countries [11] [12] [13]. 
Based on prior research, we first use event analysis method then ARMA-EGARCH-M model to test whether the volatility has obvious changes after the margin trading and securities lending mechanism was introduced, and to analyze the correlation between margin trading and securities lending transactions and market volatility. This paper mainly includes 6 parts: 1) Introduction. 2) Literature Review. 3) Model Specification. 4) Research Data. 5) Regression Analysis. 6) Conclusions.

And the empirical results show that: 1) The volatility of China's stock market is asymmetric; 2) Margin trading transactions reduce the stock market volatility while securities lending transactions increase the stock market volatility. Since the trading volume of margin trading was much larger than the trading volume of securities lending, the stock market volatility decreased since the launch of margin trading and securities lending mechanism.

The possible contributions of this paper are as follows: Firstly, the existing literature mainly studies the impact of margin trading and securities lending on short-term fluctuations in the stock market. This paper also studies the long-term effects of margin trading and securities lending and stock market volatility asymmetry. Secondly, when studying the market impact of margin trading and securities lending, we also consider the impact of the transactions of stock index futures on the stock market, so the research conclusions are more stable. Thirdly, it provides an empirical test for whether China's margin trading and securities lending transactions will help increase or decrease the market volatility. And it not only provides a reference for the regulatory authorities to improve stock market mechanisms and regulatory measures, but also has certain reference value for investors' decision-making.

\section{Model Specification}

In order to test whether the volatility has obvious changes after the margin trading and securities lending mechanism was introduced, and to analyze the correlation between margin trading and securities lending transactions and market volatility, this paper will first use event analysis method then ARMA-EGARCH-M model.

\subsection{Event Analysis Method}

The event analysis method mainly focuses on whether the relevant variables have statistically significant differences before and after the event. Generally speaking, the steps involved mainly include: determining the time when the event occurs, determining the time window period, the estimation period and the data sample of the study, calculating the relevant variables, and performing statistical tests.

This paper first takes the Shanghai and Shenzhen 300 Index (hereafter referred as CSI 300 index) as the research object, and study the change of market volatility after the margin trading and securities lending mechanism was introduced. In April 2010, when the incident occurred, the volatility during the pe- 
riod of 60, 180 and 360 trading days forward and backward, were estimated. Then non-parametric test was used to analyze whether the volatility has a statistically significant change.

\subsection{Variables Selection of Volatility Estimation}

This paper calculates two types of volatility. One is historical volatility, and the other is estimation volatility. This paper mainly selects Parkinson estimator (Parkinson) and Rogers et al. estimator (RSY) [14] [15].

The Parkinson estimator expression is:

$$
\sigma=\sqrt{\frac{1}{4 N \ln 2} \sum_{t=1}^{N}\left(\ln \frac{h_{t}}{l_{t}}\right)^{2}}
$$

$h_{t}$ denotes the highest price in the trading session, $l_{t}$ denotes the lowest price in the trading session.

Tong Bin et al. [16] pointed out that Parkinson estimator is five times more efficient than estimators based on closing prices. But the Parkinson estimator method relies on assumptions (that prices obey the geometric Brownian motion without drift terms and that transactions are continuous) that are not applicable in the real market. Rogers et al. relaxed these constraints to some extent, and introduced a better estimator with drift terms [15]. The expression of the Rogers-Satchell-Yoon estimator is

$$
\sigma=\sqrt{\frac{1}{N} \sum_{i=1}^{N}\left[\left(\ln \frac{h_{i}}{l_{i}}\right)\left(\ln \frac{h_{i}}{o_{i}}\right)+\left(\ln \frac{l_{i}}{c_{i}}\right)\left(\ln \frac{l_{i}}{o_{i}}\right)\right]}
$$

$h_{t}$ denotes the highest price in the trading session, $l_{t}$ denotes the lowest price of the trading session, $c_{i}$ denotes the closing price of the trading session, $o_{i}$ denotes the closing price of the trading session.

\subsection{ARMA-EGARCH-M Model}

Estimation volatility is often used to predict the actual volatility of an asset. The GARCH model proposed by Bollerslev is considered to be a good description of the fat-tailedness and the clustering of fluctuations in the distribution of financial assets, and is widely used in financial time series analysis [17].

The general expression of the variance equation of the GARCH $(p, q)$ model is

$$
\sigma^{2}=\alpha_{0}+\sum_{i=1}^{p} \alpha_{i} \sigma_{t-i}^{2}+\sum_{j=1}^{q} \beta_{j} \mu_{t-j}^{2}
$$

Since the volatility in the GARCH model is calculated from the square values of the historical data, the GARCH model does not explain the effect of stock returns on volatility. The EGARCH model proposed by Nelson can better describe this asymmetry [12]. If the downward volatility of the index is greater than the upward volatility, it is called the leverage effect. The variance equation expression for this model is:

$$
\ln \sigma_{t}^{2}=\alpha_{0}+\sum_{i=1}^{p} \alpha_{i} \ln \sigma_{t-i}^{2}+\sum_{j=1}^{p} \beta_{j}\left[\theta z_{t-j}+\gamma\left(\left|z_{t-j}\right|-E\left|z_{t-j}\right|\right)\right]
$$




$$
z_{t}=\frac{\mu_{t}}{\sigma_{t}}
$$

Different from the GARCH model, the conditional variance in EGARCH model is in the form of a logarithm, which makes the predicted value of the conditional variance greater than zero. When estimating the parameters, it is no longer necessary to have the non-negative limit. As long as it is significantly different from zero, the shock impact is considered to be asymmetrical.

Considering that margin trading and securities lending transactions may have different degrees of influence on volatility in the bull and bear market, and in order to test whether bull and bear state of the stock market has an impact on volatility, according to the previous research results, this paper selects ARMA-EGARCH-M model to study. Based on the Nelson model, we take more variables into consideration: the stock index closing price, stock market trading volume, dummy variable of bull and bear state of the stock market, volume of margin trading transactions, volume of securities lending transactions and volume of stock index futures transactions. ARMA-EGARCH-M model is as follows:

$$
\begin{gathered}
R_{t}=\alpha_{0}+\alpha_{1} R_{t-1}+\alpha_{2} R_{t}^{I F 00}+\alpha_{3} \sigma_{t}^{2}+u_{t} \\
u_{t}=\sum_{i=1}^{p} \rho_{i} u_{t-i}+\sum_{j=1}^{q} \theta_{j} \varepsilon_{t-j}+\varepsilon_{t} \\
\ln \left(\sigma_{t}^{2}\right)=\beta_{0}+\sum_{k=1}^{m} \phi_{i} \ln \left(\sigma_{t-k}^{2}\right)+\sum_{l=1}^{n} \varphi_{l}\left|z_{t-l}\right|+\gamma_{1} z_{t-1}+\gamma_{2} N_{t}+\gamma_{3} D_{t}^{\text {bull }} \\
+\gamma_{4} P_{t}+\gamma_{5} V_{t}+\gamma_{6} Q_{t}^{\text {mr }}+\gamma_{7} Q_{t}^{s s}+\gamma_{8} Q_{t}^{I F 00}+\gamma_{9} D_{t}^{\text {bull }} P_{t} \\
+\gamma_{10} D_{t}^{\text {bull }} V_{t}+\gamma_{11} D_{t}^{\text {bull }} Q_{t}^{\text {mr }}+\gamma_{12} D_{t}^{\text {bull }} Q_{t}^{s s}+\gamma_{13} D_{t}^{\text {bull }} Q_{t}^{I F 00}
\end{gathered}
$$

$R_{t}$ is the stock index return rate on the trading day $t$. The introduction of $R_{t-1}$ to the mean value equation can reflect the yield autocorrelation due to the non-continuous trading of the stock market; $\sigma_{t}^{2}$ is the conditional variance of the excess return rate $u_{t}$. Some studies find that the expected return rate of the stock is significantly positively correlated with volatility [11]; $N_{t}$ is the number of non-trading days between trading days, which captures the impact of non-trading day information on stock market volatility [12].

$R_{t}^{I F 100}$ is the yield rate of daily opening price of the CSI 300 stock index futures contracts on the trading day $t$. The introduction of stock index futures yield rate in the mean value equation can reflect the price discovery function of stock index futures and its price guiding effect on the spot market [18] [19]. China's stock index futures opens earlier in the morning than the stock market, and the closing time in the afternoon is later than the stock market. Therefore, the stock index futures yield in the model should not use the closing price of the day. Considering that correlation between the yield rate of daily opening price of the stock index futures and the stock index return rate is higher, the yield rate of daily opening price is used as the stock index futures yield variable.

$D^{\text {bull }}$ denotes whether the trading day is in a bull market. The time between the peak to the trough is assigned a value of 0 , and the trough to the peak is as- 
signed a value of 1 .

$P_{t}$ denotes the natural logarithm value of the stock market price, $V_{t}$ represents the natural logarithm value of the trading volume of the stock market. These two variables are used to capture the impact of investor sentiment due to the overall price trend and trading volume of the stock market on stock market volatility.

$Q_{t}^{M R}$ denotes the margin trading transaction variable on the trading day $t$. $Q_{t}^{S S}$ denotes the trading volume of securities lending on the trading day $t$. $Q_{t}^{M R}=$ trading volume of margin trading/trading volume of CSI 300 stock index ${ }^{\star} 100 \% . Q_{t}^{S S}=$ trading volume of securities lending/trading volume of CSI 300 stock index ${ }^{\star} 100 \%$. China’s margin trading and securities lending business began on March 31, 2010, before this time the margin trading and securities lending variables were set to zero.

$Q_{t}^{I F 00}$ denotes the trading volume of the current month contract of CSI 300 stock index futures on the trading day $t$. The introduction of trading volume of stock index futures in the conditional variance equation can catch the impact of the futures market on spot market's volatility. The calculation formula is: $Q_{t}^{I F 00}$ $=$ trading volume of the current month contract of CSI 300 stock index futures/trading volume of CSI 300 stock index ${ }^{\star} 100 \%$.

The parameters $\gamma_{1}, \cdots, \gamma_{13}$ reflect the impact of stock market bullish status, margin trading and securities lending transactions, stock index futures transactions on stock market's volatility. It is assumed that the residual term in the mean equation obeys the student $t$ distribution.

\section{Research Data}

\subsection{Sample Selection}

In order to study the impact of margin trading and securities lending transactions on stock market volatility from the market level, the CSI 300 Index was selected as the sample of research. Since the CSI 300 stock indexes were first released on April 8, 2005, the research interval of this paper is from April 8, 2005 to November 30, 2018.

\subsection{Bull and Bear Cycle Division}

To study the impact of margin trading and securities lending transactions on the stock market volatility, firstly divide the bull and bear cycle of the CSI 300 Stock Index. The stock market cycle division method is derived from the business cycle division method.

In 1971, Bry and Boschan (hereafter referred as BB) designed a NBER business cycle division method [20]. The method is simple and clear, and researchers do not need to make an in-depth analysis of the economic development. Anyone who uses this method to analyze the same data can reach the same conclusion. Pagan and Sossounov applied the BB method to study the cycle of bulls and bears of the stock market, and improved the $\mathrm{BB}$ method according to the characteris- 
tics of the stock market cycle. This paper uses the improved BB method of Pagan and Sossounov to divide the stock market cycle of the CSI 300 Index [21].

As Table 1 shows, from April 2005 to November 2018, the CSI 300 Stock Index experienced six bull-bear cycles, with an average duration of 27 months per bull-bear cycle.

\subsection{Statistical Description}

The average daily yield of the CSI 300 stock indexes was positive, indicating that the overall trend of the stock market was upward (not considering inflation); the maximum value was about $8.93 \%$, and the minimum value was about $-9.70 \%$, indicating that the stock market was very volatile and extreme. Even the daily change of the stock market index was close to the daily limits.

Table 2 gives the descriptive statistics of the day-to-day volatility of the CSI 300 Index. As the table shows, the average volatility calculated using ARMA-EGARCH-M model is $1.59 \%$, and the average values of Parkinson volatility estimator and RSY volatility estimator are $1.23 \%$ and $1.63 \%$, respectively.

Table 3 gives the correlations between the different volatility estimators. Among them, the upper right part is the Spearman correlation coefficient, the lower left part is the Pearson correlation coefficient, and the lower part of each line is the statistical $\mathrm{p}$ value. The correlation coefficients between Parkinson's volatility, RSY volatility and ARMA-EGARCH-M volatility are between 0.5147 and 0.8377 , and all p-values are less than 0.0001 , which means that all correlation coefficients are at the significance level of $1 \%$. There are significant correlations between these three estimators.

Table 1. The peaks and troughs of the CSI 300 Index in 2005-2018.

\begin{tabular}{ccc}
\hline & CSI 300 Index & \\
\hline Time & Closing price of the day & Peak \& trough judgment \\
\hline April 8, 2005 & 1003.45 & Peak \\
June 3, 2005 & 818.03 & Trough \\
October 16, 2007 & 5877.2 & Peak \\
November 4, 2008 & 1627.76 & Trough \\
August 3, 2009 & 3787.03 & Peak \\
July 5, 2010 & 2512.65 & Trough \\
November 8, 2010 & 3548.57 & Peak \\
March 20, 2014 & 2086.97 & Trough \\
June 8, 2015 & 5353.75 & Peak \\
January 28, 2016 & 2853.76 & Trough \\
January 24, 2018 & 4389.89 & Peak \\
October 18, 2018 & 3044.39 & Trough \\
\hline
\end{tabular}


Table 2. Statistical description of different volatility estimators.

\begin{tabular}{cccccc}
\hline Volatility & Sample number & Mean & $\begin{array}{c}\text { Standard } \\
\text { deviation }\end{array}$ & $\begin{array}{c}\text { Minimum } \\
\text { value }\end{array}$ & $\begin{array}{c}\text { Maximum } \\
\text { value }\end{array}$ \\
\hline $\begin{array}{c}\text { ARMA-EGARCH-M } \\
\text { Volatility }\end{array}$ & 3321 & 0.0159 & 0.0072 & 0.00414 & 0.0654 \\
$\begin{array}{c}\text { Parkinson Volatility } \\
\text { RSY Volatility }\end{array}$ & 3321 & 0.0122 & 0.00829 & 0.0021 & 0.06795 \\
\hline
\end{tabular}

Table 3. Correlations between different volatility estimators.

\begin{tabular}{cccc}
\hline Volatility & $\begin{array}{c}\text { ARMA-EGARCH-M } \\
\text { Volatility }\end{array}$ & Parkinson Volatility & RSY Volatility \\
\hline ARMA-EGARCH-M & 1.0000 & $0.600^{* * *}$ & $0.547^{* * *}$ \\
Volatility & $0.546^{* * *}$ & $<0.0001$ & $<0.0001$ \\
Parkinson Volatility & $<0.0001$ & 1.0000 & $0.835^{\star * *}$ \\
& $0.515^{* * *}$ & $0.838^{* * *}$ & $<0.0001$ \\
RSY Volatility & $<0.0001$ & $<0.0001$ & 1.0000 \\
\hline
\end{tabular}

Margin trading and securities lending mechanism was introduced to the market on March 31, 2010. And the business of the CSI 300 stock index futures began on April 15, 2010. Considering the short interval between the two incidents, there may be a superposition of their impacts on stock market volatility. Therefore, the non-parametric tests of the historical volatility estimations of 60,180 and 360 trading days before March 31, 2010 and after April 15, 2010 were carried out to test whether the introduction of the margin trading and securities lending business had any impact on the volatility of the stock market.

Table 4 shows the statistical changes in the volatility estimators on different trading intervals.

Specifically, the average values of ARMA-EGARCH-M volatility estimator, Parkinson estimator, and RSY estimator was $2.21 \%, 1.05 \%$ and $1.38 \%$, in the 60 trading days prior to the launch of the mechanism; and the average values in the 60 trading days after the launch of the mechanism were $1.74 \%, 1.42 \%$ and $1.79 \%$. The comparison results show that only the ARMA-EGARCH-M volatility has a larger decline than before, while the other two historical volatility estimators were higher than before. However, as the intervals extend, it can be found that the volatility levels have significantly reduced.

Considering that ARMA-EGARCH-M volatility estimator is based on a dynamic model to predict the actual volatility of an asset, it can better describe the thick tail and clustering of the volatility distribution. However, Parkinson volatility estimator and RSY volatility estimator are based on certain assumptions and trading data of the day. Thus the descriptive statistics of the three volatility estimators must be different. In order to investigate whether the market volatility levels after the launch of the margin trading and securities lending mechanism significantly reduced, this paper conducts a nonparametric test of the volatility data. 
Table 4. Changes of the volatility estimators before and after the mechanism.

\begin{tabular}{|c|c|c|c|c|c|c|c|}
\hline $\begin{array}{l}\text { Sample } \\
\text { Interval }\end{array}$ & Volatility & Mean & $\begin{array}{l}\text { Standard } \\
\text { Deviation }\end{array}$ & Skewness & Kurtosis & $\begin{array}{l}\text { Maximum } \\
\text { Value }\end{array}$ & $\begin{array}{l}\text { Minimum } \\
\text { Value }\end{array}$ \\
\hline \multirow{3}{*}{$\begin{array}{l}60 \text { trading } \\
\text { days before }\end{array}$} & ARMA-EGARCH-M & 0.0221 & 0.0049 & 0.8046 & 3.1518 & 0.0338 & 0.0136 \\
\hline & Parkinson & 0.0105 & 0.0049 & 1.1554 & 3.9683 & 0.0259 & 0.0039 \\
\hline & RSY & 0.0138 & 0.0066 & 1.6664 & 7.9102 & 0.0431 & 0.0045 \\
\hline \multirow{3}{*}{$\begin{array}{l}60 \text { trading } \\
\text { days after }\end{array}$} & ARMA-EGARCH-M & 0.0174 & 0.0049 & 0.8782 & 5.8130 & 0.0373 & 0.0074 \\
\hline & Parkinson & 0.0142 & 0.0061 & 0.7458 & 2.6514 & 0.0300 & 0.0057 \\
\hline & RSY & 0.0179 & 0.0096 & 0.8451 & 3.0474 & 0.0449 & 0.0036 \\
\hline \multirow{3}{*}{$\begin{array}{l}180 \text { trading } \\
\text { days before }\end{array}$} & ARMA-EGARCH-M & 0.0250 & 0.0052 & 0.5272 & 3.3022 & 0.0426 & 0.0136 \\
\hline & Parkinson & 0.0138 & 0.0078 & 1.5807 & 6.2891 & 0.0519 & 0.0039 \\
\hline & RSY & 0.0181 & 0.0101 & 1.4713 & 5.5823 & 0.0596 & 0.0045 \\
\hline \multirow{3}{*}{$\begin{array}{l}180 \text { trading } \\
\text { days after }\end{array}$} & ARMA-EGARCH-M & 0.0202 & 0.0068 & 1.2146 & 5.2395 & 0.0481 & 0.0074 \\
\hline & Parkinson & 0.0127 & 0.0059 & 1.2037 & 4.5075 & 0.0377 & 0.0038 \\
\hline & RSY & 0.0168 & 0.0086 & 0.9877 & 3.4973 & 0.0449 & 0.0036 \\
\hline \multirow{3}{*}{$\begin{array}{l}360 \text { trading } \\
\text { days before }\end{array}$} & ARMA-EGARCH-M & 0.0248 & 0.0063 & 0.5585 & 3.4959 & 0.0472 & 0.0088 \\
\hline & Parkinson & 0.0159 & 0.0085 & 1.3587 & 5.2137 & 0.0519 & 0.0039 \\
\hline & RSY & 0.0214 & 0.0120 & 1.4725 & 6.0300 & 0.0753 & 0.0038 \\
\hline \multirow{3}{*}{$\begin{array}{l}360 \text { trading } \\
\text { days after }\end{array}$} & ARMA-EGARCH-M & 0.0197 & 0.0061 & 1.1998 & 5.4371 & 0.0481 & 0.0074 \\
\hline & Parkinson & 0.0112 & 0.0055 & 1.4740 & 5.3316 & 0.0377 & 0.0038 \\
\hline & RSY & 0.0146 & 0.0081 & 1.2380 & 4.3581 & 0.0449 & 0.0015 \\
\hline
\end{tabular}

As Table 5 shows, after the introduction of the margin trading and securities lending mechanism and stock index futures, the volatility level of the CSI 300 stock index decreased significantly. Although some volatility statistics were not significant under the window of 180 trading days, but with the window period elongated, the volatility of the CSI 300 stock indexes dropped significantly at the $1 \%$ significance level.

It is worth noting that the insignificant volatility statistics are data of historical volatility estimators, but the actual volatility estimations calculated based on the ARMA-EGARCH-M dynamic model are very significant in all different window periods. It may be due to the fact that historical volatility estimators depend on extreme price values and assume continuous trade, which makes them somewhat underestimated, and in lower accuracy.

\section{Regression Analysis}

Although, we found that the volatility of the CSI 300 stock index decreased significantly after the launch of the mechanism, it is not certain about the direct reason. The decrease may also be caused by the fact that the stock market is affected by the economic cycle, which makes the investors more pessimistic, thereby reducing the transaction and thus causing the volatility to decline. Therefore, we construct the ARMA-EGARCH-M model. 
Table 5. Nonparametric test of the volatility data before and after the mechanism.

\begin{tabular}{cccccc}
\hline Window period & Volatility estimator & $\begin{array}{c}\text { Wilcoxon } \\
\text { estimation }\end{array}$ & P value & KW estimation & P value \\
\hline & ARMA-EGARCH-M & $4.871^{* * *}$ & 0.0000 & $23.724^{* * *}$ & 0.0001 \\
60 trading days & Parkinson & $-3.391^{* * *}$ & 0.0007 & $11.496^{* * *}$ & 0.0007 \\
& RSY & $-2.126^{* *}$ & 0.0335 & $4.519^{* *}$ & 0.0335 \\
& ARMA-EGARCH-M & $8.149^{* * *}$ & 0.0000 & $66.410^{* * *}$ & 0.0001 \\
$\begin{array}{c}180 \text { trading } \\
\text { days }\end{array}$ & Parkinson & 0.640 & 0.5221 & 0.410 & 0.5221 \\
& RSY & 1.099 & 0.2718 & 1.208 & 0.2718 \\
360 trading & ARMA-EGARCH-M & $11.048^{* * *}$ & 0.0000 & $122.048^{* * *}$ & 0.0001 \\
days & Parkinson & $8.739^{* * *}$ & 0.0000 & $76.370^{* * *}$ & 0.0001 \\
& RSY & $8.824^{* * *}$ & 0.0000 & $77.855^{* * *}$ & 0.0001 \\
\hline
\end{tabular}

Taking the CSI 300 stock index as the sample, we will make the maximum likelihood estimation of the ARMA-EGARCH-M model. According to the AIC and SC guidelines, the model of the CSI 300 stock index is determined to be $\operatorname{ARMA}(1,1)$-EGARCH(1,1)-M.

The regression results of the model are shown in Table 6.

1) The autocorrelation of the daily returns of the stock index is very significant. The estimation results of $\alpha_{1}$ in all models are significant at the $1 \%$ significance level, indicating that the market yield of the previous trading day can be used to predict the market rate of return on the current trading day, which meets the basic requirements of the ineffective market.

2) The stock index futures trading has a significant impact on the stock index yield on the day. The parameter $\alpha_{2}$ is approximately equal to 0.17 , and is significant at the $1 \%$ level, indicating that if the opening price of the CSI 300 stock index futures contract rise by $1 \%$, then the closing price of the CSI 300 stock index will rise by $0.18 \%$. It can be seen that stock index futures have a strong price guiding effect on the spot market, which is consistent with the research conclusions of Zuo Haomiao et al. (2012) and Tao Libin et al. (2014).

3) The estimated values of the risk premium in each model are positive, and the parameters of the conditional variance of Model 2 and Model 3are significant at the $1 \%$ significance level, indicating that the investors are risk aversive. It is consistent with the theoretical analyses and empirical results of the capital asset pricing model, and also consistent with the findings of French et al. (1987).

4) The ARMA effect is significant, and the parameters $\rho$ and $\theta$ are significant at the $1 \%$ significance level, indicating that the disturbance term conforms to the ARMA $(1,1)$ process. The special information of the previous trading day still has a significant impact on the current daily yield.

5) The EGARCH_a parameter $\varphi$ in the model is significantly positive in each model, and the scale of symmetry effect is larger than the asymmetry effect.

6) The estimations of $N_{t}$ are about 0.13 , which are significant at the $1 \%$ significance level, indicating that non-trading day information has a significant impact on stock index volatility. 
Table 6. Regression results.

\begin{tabular}{|c|c|c|c|c|}
\hline & Model 1 & Model 2 & Model 3 & Model 4 \\
\hline$\alpha_{0}$ & $\begin{array}{c}-0.0044^{*} \\
(0.0026)\end{array}$ & $\begin{array}{c}-0.0049^{*} \\
(0.0028)\end{array}$ & $\begin{array}{l}-0.0014^{* *} \\
(-0.0007)\end{array}$ & $\begin{array}{l}-0.0001 \\
(.00081)\end{array}$ \\
\hline$\alpha_{1}$ & $\begin{array}{c}-0.1431^{* * *} \\
(0.0220)\end{array}$ & $\begin{array}{c}-0.1408^{* * *} \\
(0.0225)\end{array}$ & $\begin{array}{c}-0.1579 * * * \\
(0.0163)\end{array}$ & $\begin{array}{c}-0.1486^{* * *} \\
(0.01664)\end{array}$ \\
\hline$\alpha_{2}$ & $\begin{array}{l}0.2229^{* * *} \\
(0.0245)\end{array}$ & $\begin{array}{c}0.2221^{* * *} \\
(0.0244)\end{array}$ & $\begin{array}{c}0.1953^{* * *} \\
(0.0203)\end{array}$ & $\begin{array}{c}0.1754^{* * *} \\
(0.0212)\end{array}$ \\
\hline$\alpha_{3}$ & $\begin{array}{c}0.2971 \\
(1.9475)\end{array}$ & $\begin{array}{c}0.2637 \\
(1.9990)\end{array}$ & $\begin{array}{c}14.8359^{* * *} \\
(1.9095)\end{array}$ & $\begin{array}{l}9.1304^{* * *} \\
(1.63685)\end{array}$ \\
\hline$\rho$ & $\begin{array}{l}1.0011^{* * *} \\
(0.00087)\end{array}$ & $\begin{array}{l}1.0009^{* * *} \\
(0.0007)\end{array}$ & $\begin{array}{c}0.9968^{* * *} \\
(0.0015)\end{array}$ & $\begin{array}{l}0.9955^{\star * *} \\
(0.00227)\end{array}$ \\
\hline$\theta$ & $\begin{array}{c}-0.9842^{* * *} \\
(0.0032)\end{array}$ & $\begin{array}{c}-0.9842 * * * \\
(0.0032)\end{array}$ & $\begin{array}{c}-0.9907^{* * *} \\
(0.0026)\end{array}$ & $\begin{array}{c}-0.9824^{* * *} \\
(0.0038)\end{array}$ \\
\hline$\beta_{0}$ & $\begin{array}{c}-0.0472^{* *} \\
(0.0194)\end{array}$ & $\begin{array}{c}-0.1546^{* * *} \\
(0.0341)\end{array}$ & $\begin{array}{c}-30.287^{* * *} \\
(1.371768)\end{array}$ & $\begin{array}{c}-28.368^{* * *} \\
(2.3001)\end{array}$ \\
\hline$\phi$ & $\begin{array}{c}0.9932^{* * *} \\
(0.0023)\end{array}$ & $\begin{array}{l}0.9821^{* * *} \\
(0.00422)\end{array}$ & $\begin{array}{c}-0.5111^{* * *} \\
(0.0424)\end{array}$ & $\begin{array}{c}-0.5139^{* * *} \\
(0.0387)\end{array}$ \\
\hline$\varphi$ & $\begin{array}{c}0.1322^{* * *} \\
(0.0153)\end{array}$ & $\begin{array}{c}0.1318^{* * *} \\
(0.0172)\end{array}$ & $\begin{array}{c}0.1192^{\star * *} \\
(0.0325)\end{array}$ & $\begin{array}{c}0.0991^{* * *} \\
(0.0347)\end{array}$ \\
\hline$\gamma_{1}$ & $\begin{array}{c}-0.0234^{* *} \\
(0.0099)\end{array}$ & $\begin{array}{c}-0.0326^{* * *} \\
(0.0121)\end{array}$ & $\begin{array}{l}-0.0008 \\
(0.0235)\end{array}$ & $\begin{array}{l}-0.0367 \\
(0.0238)\end{array}$ \\
\hline$\gamma_{2}$ & & $\begin{array}{c}0.0517^{\star * *} \\
(0.0172)\end{array}$ & $\begin{array}{c}0.1240^{\star * *} \\
(0.0201)\end{array}$ & $\begin{array}{c}0.1390^{* * *} \\
(0.0217)\end{array}$ \\
\hline$\gamma_{3}$ & & $\begin{array}{l}-0.0047 \\
(0.0072)\end{array}$ & & $\begin{array}{l}-2.1654 \\
(2.6280)\end{array}$ \\
\hline$\gamma_{4}$ & & & $\begin{array}{c}-0.5527^{* * *} \\
(0.1431)\end{array}$ & $\begin{array}{c}-0.7566^{* * *} \\
(0.2738)\end{array}$ \\
\hline$\gamma_{5}$ & & & $\begin{array}{l}1.7346^{* * *} \\
(0.09611)\end{array}$ & $\begin{array}{c}1.7318^{\star * *} \\
(0.1382)\end{array}$ \\
\hline$\gamma_{6}$ & & $\begin{array}{l}-0.0012 \\
(.00093)\end{array}$ & $\begin{array}{c}-0.2991^{\star * *} \\
(0.0162)\end{array}$ & $\begin{array}{c}-0.2200^{\star * *} \\
(0.0241)\end{array}$ \\
\hline$\gamma_{7}$ & & $\begin{array}{l}0.0272^{\star} \\
(0.0144)\end{array}$ & $\begin{array}{c}0.8935^{* * *} \\
(0.1214)\end{array}$ & $\begin{array}{l}0.4103^{* *} \\
(0.1840)\end{array}$ \\
\hline$\gamma_{8}$ & & $\begin{array}{c}-0.0051^{* *} \\
(0.0022)\end{array}$ & $\begin{array}{c}-0.1013^{* * *} \\
(0.0190)\end{array}$ & $\begin{array}{c}-0.1546^{* * *} \\
(0.0259)\end{array}$ \\
\hline$\gamma_{9}$ & & & & $\begin{array}{c}-0.9531^{* * *} \\
(0.3404)\end{array}$ \\
\hline$\gamma_{10}$ & & & & $\begin{array}{c}0.6546^{* * *} \\
(0.1930)\end{array}$ \\
\hline$\gamma_{11}$ & & $\begin{array}{c}-0.0028^{*} \\
(0.0014)\end{array}$ & & $\begin{array}{c}-0.1407^{* * *} \\
(0.0311)\end{array}$ \\
\hline$\gamma_{12}$ & & $\begin{array}{c}0.0146 \\
(0.0192)\end{array}$ & & $\begin{array}{c}0.8240^{* * *} \\
(0.2705)\end{array}$ \\
\hline$\gamma_{13}$ & & $\begin{array}{c}0.0009 \\
(0.0032)\end{array}$ & & $\begin{array}{c}0.1039 * * * \\
(0.0423)\end{array}$ \\
\hline
\end{tabular}

7) The parameter $\gamma_{1}$ are significantly negative in model 1 (with no other influencing variables), model 2 (without considering stock market closing prices and volume variables), but are not significantly negative in models 3 . The reason why the asymmetry effect in model 3 and model 4 is not significant may be the introduction of the two explanatory variables to the conditional variance equation: the stock market closing price level and trading volume. Note that the parameter estimations are negative, indicating that the impact of good news on stock market volatility is less than bad news. 
8) The parameters $\gamma_{4}$ and $\gamma_{9}$ are significantly negative at the $1 \%$ significance level, which indicates that the closing price of the CSI 300 stock index has a significant impact on the volatility of the index. When the CSI 300 stock index rises, the volatility tends to decrease. The CSI 300 stock index has fluctuation asymmetry in both bull and bear market, and the fluctuation asymmetry in the bull market is larger than that in the bear market. The reason may be that investors in all are more sensitive to the price level in bull market than in the bear market. In other words, the market is more volatile in the bull market. In most cases, there are more sensitive retail investors in the bull market and they are used to follow others, the herd effect is obvious.

9) The parameters $\gamma_{5}$ and $\gamma_{10}$ are both significantly positive, indicating that the larger the spot volume of the CSI 300 stock index is, the greater the possibility of an extreme index price appears, and the greater the index volatility will be. This is consistent with previous research results. It is worth noting that the volatility of the CSI 300 stock index was more easily affected by the stock market trading volume than in the bear market.

10) The parameters of margin trading transactions are significantly negative, indicating that margin trading transactions help to reduce market volatility.

11) The parameters of securities lending transactions are significantly positive, indicating the introduction of securities lending transactions resulted in an increase in overall market volatility. It is worth noting that the estimated value of the parameter in the bull market is larger than that in the bear market, indicating that the securities lending can amplify the fluctuation of the stock market in the bull market in larger scale than in bear market.

12) The parameters of stock index futures transactions are significantly negative, indicating that the introduction of stock index futures trading can reduce the volatility of the CSI 300 stock index. It is worth noting that the estimated value of the parameter in the bear market is larger than that in the bull market, indicating that stock index futures can more restrain the market fluctuations in the bear market in larger scale than in bull market.

\section{Conclusions}

The lack of a two-way trading mechanism has long been considered to be one of the most important reasons why China's stock market is so volatile. Most investors expect that the launch of margin trading and securities lending business in 2010 will stabilize stock market volatility and play a role as a market stabilizer. However, during the period of sharp fluctuations in A-shares from 2014 to 2015, many people doubted that margin trading and securities lending business intensified stock market volatility significantly. Whether margin trading and securities lending mechanism helped to increase or decrease stock market volatility sparked heated discussions. Based on the asymmetric view of stock market volatility, the empirical results of this paper show that there is a significant asymmetry in China's stock market volatility, and the securities lending business can 
amplify the volatility of the stock index, and the stock index futures transactions and margin trading business can significantly reduce the fluctuation of the stock index.

The research in this paper has certain theoretical and practical significance. Theoretically, this paper analyzes the impact of margin trading and securities lending on the cyclical fluctuation of stock market based on the asymmetric view of stock market volatility, and expands the research on the impact of margin trading and securities lending on stock market volatility. In terms of policy implications, the research conclusions show that margin financing and securities lending will significantly affect the long-term volatility of the stock market. China should timely learn from the practice of margin trading and securities lending in recent years, and learn from the foreign developed markets to continuously improve the margin financing and securities lending system.

In addition, considering that China's stock market is relatively young, large fluctuations are common. When the market's expectation is different from reality, it is easy to generate systemic risks. Before the introduction of margin trading and securities lending mechanism and stock index futures business, investors have insufficient options to hedge, which will lead to market fluctuations. Therefore, in order to alleviate the large fluctuations in the market, it is necessary to introduce more derivatives to the market. Derivatives can serve as an "automatic stabilizer" for the capital market, thereby attracting more corporate investors to enter the market and make long-term investments. In terms of investment strategy, when there are rich derivatives, there will be a variety of hedging and arbitrage strategies in the market. We should see the benefits of such neutral strategies.

\section{Conflicts of Interest}

The author declares no conflicts of interest regarding the publication of this paper.

\section{References}

[1] De Long, J.B., Shleifer, A., Summers, L.H. and Waldmann, R.J. (1990) Noise Trader Risk in Financial Markets. Journal of Political Economy, 98, 703-738. https://doi.org/10.1086/261703

[2] Li, K., Xu, L. and Zhu, W. (2014) Short-Sale Constrains and Stock Mispricing: The Evidence from the Margin Transactions Institution. Journal of Economic Research, 10, 166-178.

[3] Li, Z., Du, S. and Lin, B. (2015) Short Selling and Stock Price Stability: Natural Experiments from China's Margin Financing Market. Journal of Financial Research, 6 , 173-188.

[4] Xiao, H. and Kong, A. (2014) Study on the Influence Mechanism of Margin Financing on Stock Price Traits Fluctuation: Test Based on Double Difference Model. Management World, 8, 30-43.

[5] Chen, H. and Fan, Y. (2015) Financing and Margin Trading System vs. China Stock 
Market Volatility: An Analysis Based on Panel Data Policy Evaluation Method. Journal of Financial Research, 6, 159-172.

[6] Xu, H. and Chen, X. (2012) Does China's Launch of Margin Financing and Securities Lending Transactions Promote the Pricing Efficiency of the Underlying Stocks? Management World, 5, 52-61.

[7] Li, F. (2017) Does Margin Trading Aggravate Stock Market Fluctuation? From the Perspective of Asymmetric Volatility. Journal of Financial Research, 2, 147-162.

[8] Lin, X., Yi, F. and Chen, C. (2016) The Effect of Marginal and Financing Trading: A Study Based on the Double Difference Model. Investment Research, 4, 74-86.

[9] Zhu, J. and Fang, J. (2016) Chinese-style Margin Financing System Arrangement and Deterioration of Stock Price Crash Risk. Economic Research Journal, 5, 143-158.

[10] Black, F. (1976) Studies of Stock Price Volatility Changes. Proceedings of the 1976 Meetings of the Business and Economics Statistics Section, American Statistical Association, Washington DC, 177-181.

[11] French, K.R., Schwert, G.W. and Stambaugh, R.F. (1987) Expected Stock Returns and Volatility. Journal of Financial Economics, 19, 3-29. https://doi.org/10.1016/0304-405X(87)90026-2

[12] Nelson, D.B. (1991) Conditional Heteroskedasticity in Asset Returns: A New Approach. Econometrica, 59, 347-370. https://doi.org/10.2307/2938260

[13] Engle, R.F. and Ng, V.K. (1993) Measuring and Testing the Impact of News on Volatility. The Journal of Finance, 48, 1749-1778. https://doi.org/10.1111/j.1540-6261.1993.tb05127.x

[14] Parkinson, M. (1980) The Extreme Value Method for Estimating the Variance of the Rate of Return. Journal of Business, 53, 61-65. https://doi.org/10.1086/296071

[15] Rogers, L.C.G., Satchell, S.E. and Yoon, Y. (1994) Estimating the volatility of stock Prices: A comparison of Methods That Use High and Low Prices. Applied Financial Economics, 4, 241-247. https://doi.org/10.1080/758526905

[16] Tong, B., Zhang, C. and Xiao, L. (2013) Volatility Trading. Shanghai Jiaotong University Press, Shanghai.

[17] Bollerslev, T. (1986) Generalized Autoregressive Conditional Heteroskedasticity, Journal of Econometrics, 31, 307-327.

[18] Zuo, H., Liu, Z. and Zeng, H. (2014) Study on Volatility Spillover and Information Transmission in Stock Index Futures and Spot Markets Based on High Frequency Data. Financial Research, 4, 140-154.

[19] Tao, L., Pan, Y. and Huang, Y. (2014) Changes in the Price Discovery Capability of Shanghai and Shenzhen 300 Stock Index Futures and Its Determinants. Journal of Financial Research, 4, 128-142.

[20] Bry, G. and Boschan, C. (1971) Cyclical Analysis of Time Series: Selected Procedures and Computer Programs. NBER, New York.

[21] Pagan, A.R. and Sossounov, K.A. (2003) A Simple Framework for Analysing Bull and Bear Markets. Journal of Applied Econometrics, 18, 23-46.

https://doi.org/10.1002/jae.664 